\title{
Active Packaging Techniques to Reduce Post-Harvest Loss in Perishables with Special Reference to Mango (cv. Dushari)
}

\author{
Ranjeet Singh $^{\dagger}$ and S K Giri ${ }^{\ddagger}$ \\ tICAR-Central Institute of Post-Harvest Engineering \& Technology, Ludhiana Punjab-141 004 India \\ $\neq$ ICAR-Central Institute of Agricultural Engineering, Nabi-Bagh, Bearsia Road Bhopal-462 038 India \\ Received 05 Jan 2018, Accepted 07 March 2018, Available online 09 March 2018, Vol.8, No.2 (March/April 2018)
}

\begin{abstract}
All horticultural produce continue their metabolic activities soon after harvest and during storage period. Modified atmospheric packaging is a common practice to minimize postharvest losses and extend shelf life of the produce. Even under modified atmosphere the control of respiration rate of the produce is limited. Optimal packaging micro environment can be adversely affected by dynamic changes in temperature and relative humidity throughout the storage period and under transportation. As an alternative, active packaging technologies provide interactive controls between the produce, package and surrounding environment to achieve and retain optimal atmospheric conditions inside the packages. Various active packaging technologies have been developed and are commercially available for a range of food products including horticultural produce and the combination of these with other postharvest management strategies offers benefits to extend shelf life. This paper reviews the recent active packaging technologies and their applications focused on horticultural produce such as Mango.
\end{abstract}

Keywords: Active Packaging, Respiration rate, Package design, Shelf life

\section{Introduction}

${ }^{1}$ Traditional food packaging is meant for protection, communication, convenience and containment (Paine 1991; Robertson 2006). The package is used to protect the product from the deteriorative effects of external environmental conditionals like heat, light, presence or absence of moisture, pressure, microorganisms, gaseous emissions and so on. It also provides the consumer with the greater ease of use and time saving convenience and contain product of various size and shapes (Yam et al. 2005). The key safety objective for traditional packaging materials which comes in contact with food is to be inert as possible. While the smart packaging systems like active and intelligent packaging concepts are based on the useful interaction between packaging environment and the food to provide active protection to the food.

\section{Active Packaging}

Active packaging can be defined as a system in which the product, package and the environment interact in a positive way to extend the shelf life or to achieve some characteristics (Miltz et al. 1995). Packaging may be termed active when it performs some role other than providing an inert barrier to the external environment

*Corresponding author's ORCID ID: 0000-0003-4766-515X, DOI: https://doi.org/10.14741/ijcet/v.8.2.8
(Rooney 1995). Active packaging can also be defined as a packaging type that changes the condition of the packaging to extend the shelf life or to improve safety or sensory properties while maintaining the quality of the packaged food (Ahvenainen 2003). Active ingredients are intended to extend the shelf life or to maintain or improve the condition of packaged food.

They are designed to deliberately incorporate components that would play an important role such as to release or absorb substances into or from the packaged food or environment surrounding the food (Sivertsvik 2007).The main goal and objective of active packaging is to extend the preservation of food in the package and enhance shelf life by involving application of various strategies like temperature control, oxygen removal, moisture control, addition of chemicals such as salt, sugar, carbon dioxide or natural acids or a combination of these with effective packaging (Robertson 2006).

These developments in active packaging applications bring advances in many areas including delayed oxidation in foods, controlled respiration rate in horticultural products, microbial growth, ethylene and moisture migration in fresh fruits and vegetables. In addendum, active packaging precisely manipulates the selectivity to modify the atmospheric concentration of gaseous compounds inside the package by coating, micro perforation, lamination, co extrusion, or polymer blending. (Brody et al. 2008). The most widely used 
active packaging technology for foods today are oxygen scavengers. The presence of oxygen in a package accelerates the oxidative deterioration of food. Oxygen facilitates the growth of aerobic microbes, off flavor and odour development, colour changes and nutritional losses and overall shelf life stability of muscle foods (Hogan and Kerry 2008). Carbon dioxide can be added to the packaging environment to suppress the microbial growth in certain products such as fresh meat, poultry, fish, cheese, and backed goods (Lopez-Rubio et al. 2004) and to reduce the respiration rate of fresh produce (Labuza 1996). Antimicrobial packing is a form of active packaging in which the packaging acts to reduce, inhibit or retard the growth of microorganisms that may be present in the packaged food or packaging material itself (Appendini and Hotchkiss 2002). A major cause of food spoilage is the presence of moisture and the purpose of moisture regulator is to lower the water activity of the product to suppress the microbial growth (Vermeiren et al.1999). In the case of fresh fruits and vegetables, respiration followed by condensation occurs when one part of the package is cooler than the other areas. Ethylene is a natural plant growth hormone which accelerates respiration of fruits and vegetables, induces fruit ripening, fruit softening and senescence even at low concentration (Abeles et al.1992). It causes yellowing of vegetables, russet spotting on lettuce and has detrimental impact on shelf life of many fruits and vegetables (Zagory 1995). Potassium permanganate immobilized on inert minerals are available in sachets for packages and blankets that can be placed in product holding rooms without integrating into the food contact packaging material (Day 2003). Activated carbon base with various metal catalysts also removes ethylene effectively. Activated charcoal impregnated with palladium catalyst is also used to scavenge ethylene from fresh produce. SedoMate $\AA$ (Japan), NeupalonTM (Japan), Hatofresh $\AA$ (Japan) is some of the commercial sachets based on activated carbon capable of scavenging ethylene (Rooney 2005).

\section{MAP Vs Active Packaging}

Modified atmosphere packaging (MAP) and Controlled atmosphere (CA) storage are well established technologies effectively used for prolonging the shelflife period of fresh or minimally processed foods. Two aspects involve in using these technologies/ process are the respiration of the products and the gas exchanges properties through the package materials, both lead to the increase of $\mathrm{CO}_{2}$ and depletion of $\mathrm{O}_{2}$ in MAP and control $\mathrm{O}_{2}$ and $\mathrm{CO}_{2}$ atmosphere in CA (Rai and Paul, 2007). The package should maintain an optimal atmosphere that will reduce respiration and slow down the physiological and microbiological changes that decrease shelf life. Most of the climacteric fruits such as Mango, Banana, Guava etc. are packed in modified atmospheric packages to control the respiration and ripening rates. For fresh produce, the use of passive MAP is limited mainly by the unavailability of appropriate film with desired thickness that provide both gases fluxes, selectivity, and temperature compensation to function effectively (Examaet al, 1993). Furthermore, these packaging technologies in combination with refrigeration can delay the deterioration of the fresh produce but, not always sufficient for maintaining the quality for the desirable marketing period.

\section{Material and methods}

\subsection{Respiration rate study of mango}

The respiration rate of mangoes was determined as per the method adopted by Singh (2014). An air tight glass container was developed for measurement of respiration rate of mango. A Headspace Analyzer (Fig 1) was used to measure the level of $\mathrm{O}_{2}, \mathrm{CO}_{2}$ and $\mathrm{N}_{2}$ inside the container at every 30 minute intervals until equilibrium was achieved. Respiration rates of the mature raw mangoes were measured at different storage temperatures $\left(10,15,20,25{ }^{\circ} \mathrm{C}\right.$ and room temperature). The respiration rates in terms of $\mathrm{CO}_{2}$ evolution (ml) per $\mathrm{kg}$ of fruits are given in Table 1.

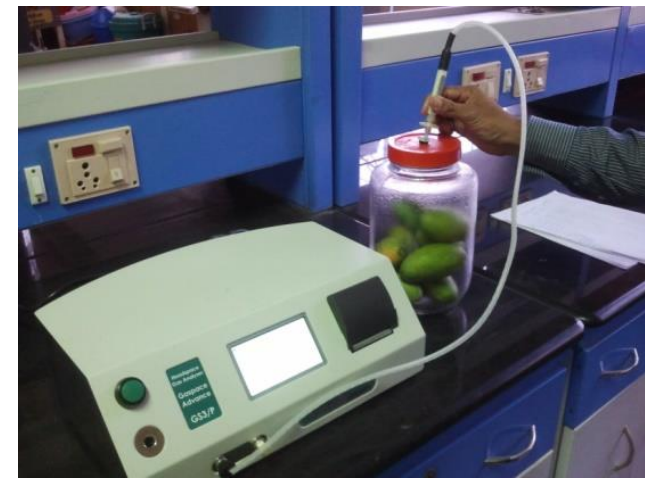

Fig. $1 \mathrm{O}_{2}$ and $\mathrm{CO}_{2}$ measurement of mango fruits in closed system

\subsection{Package Design}

Active modified atmosphere packages were designed based on the respiration rates of the mangoes, film parameters and environment factors. Film parameters such as water vapour transmission rate (WVTR), oxygen transmission rate $\left(\mathrm{O}_{2} \mathrm{TR}\right)$ and carbon dioxide transmission rate $\left(\mathrm{CO}_{2} \mathrm{TR}\right)$ of the films were measured Based on design calculations using PACK-in-MAP software perforated polypropylene (PP) film and Low density poly ethylene (LDPE) film was selected for study.

\subsection{Active packaging study}

Matured mango fruits (cv. Dusheri) were harvested from local farm, washed with citric acid solutions and 
given a brief exposure to hot air $\left(50{ }^{\circ} \mathrm{C}\right)$ for surface disinfections. Initial TSS, TA, firmness and colour values of fresh mangoes were measured. The fresh fruits had a TSS value of $10.2{ }^{\circ} \mathrm{Bx}$, TA of $0.62 \%$, and firmness (to compress $5 \mathrm{~mm}$ ) value of $25.8 \mathrm{kgf}$. The fruits were packed in polymeric films (LDPE, $75 \mu \mathrm{m}$ ) packs with ethylene absorbent sachets.

No of Hole: 10/ side of film; Size of Hole: $0.5 \mathrm{~mm}$

The MA packages inside 3 ply corrugated paper boxes were stored inside a environmental chamber at $14 \pm 1$ ${ }^{\circ} \mathrm{C}$ (Fig.2). Control (un-packaged) samples were kept at $14 \pm 1{ }^{\circ} \mathrm{C}$ for comparison.

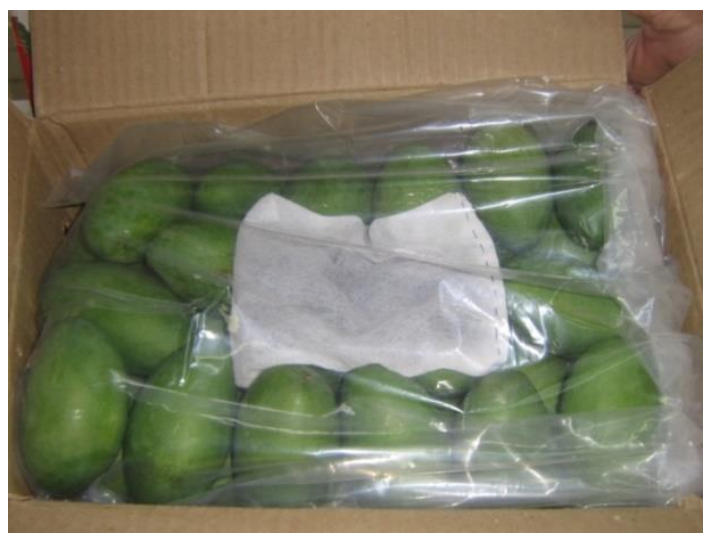

Fig.2 Active package of mangoes with absorbents

The study was carried out with following 3 treatments:

1) Control (refrigerated)

2) MAP with Potassium permanganate (PP) as ethylene absorbent (refrigerated)

3) MAP with Potassium permanganate + salicylic acid $(\mathrm{PP}+\mathrm{SA}) @ 0.15 \mathrm{~g} / \mathrm{lit}$, as ethylene absorbent (refrigerated).

\subsection{Shelf life study}

Based on in-pack gas compositions and quality parameters such as firmness, TSS, and PLW of fruits measured at regular intervals were used to assess their shelf-life.

\section{Results and discussion}

\subsection{Respiration rate}

Based on close system study the respiration rate of mangoes were $16.12,25.08$ and $32.13 \mathrm{ml} \mathrm{CO} / \mathrm{kg}$-hr at 10,15 and $20^{\circ} \mathrm{C}$ temperature, respectively. At ambient condition, the respiration rate value was $54.22 \mathrm{ml}$ $\mathrm{CO}_{2} / \mathrm{kg}-\mathrm{hr}$.

It is also concluded that the respiration rate of mangoes were increasing with the increase in temperature from $10^{\circ} \mathrm{C}$ to ambient storage. The respiration rate was high due to high metabolic reaction with increase in temperature. The detail of the respiration rate of mangoes was given in Table 1.
Table 1 Respiration rate of mangoes at different temperatures

\begin{tabular}{|c|c|}
\hline $\begin{array}{c}\text { Storage } \\
\text { temperature }\left({ }^{\circ} \mathrm{C}\right)\end{array}$ & Respiration rates $\left(\mathrm{ml} \mathrm{CO}_{2} / \mathrm{kg}-\mathrm{hr}\right)$ \\
\cline { 2 - 2 } & mango (cv. Dusheri) \\
\hline 10 & 16.12 \\
\hline 15 & 25.08 \\
\hline 20 & 32.13 \\
\hline Ambient $(40)$ & 54.22 \\
\hline
\end{tabular}

\subsection{Package design}

Using PACK-in-MAP software the package design was done for storage study of mangoes. The design parameters such as Produce parameters, Packaging film parameters and Storage condition parameters were detailed in Table 2 as under:

Table 2 Package design details

\begin{tabular}{|c|c|c|}
\hline Package properties & Unit & Value \\
\hline Weight of package & $\mathrm{kg}$ & 10 \\
\hline Bulk Density & $\mathrm{kg} / \mathrm{m}^{3}$ & 821 \\
\hline Respiration rate (RR) & $\mathrm{ml}-\mathrm{CO}_{2} / \mathrm{kg}-\mathrm{h}$ & 25.05 \\
\hline Type of film & & LDPE \\
\hline Thickness of film & $\mu \mathrm{m}$ & 75 \\
\hline Area of packaging film & $\mathrm{m}^{2}$ & 0.52 \\
\hline Headspace & $\%$ & 10 \\
\hline Desired oxygen $\left(\mathrm{O}_{2}\right)$ & $\%$ & $3-7$ \\
\hline $\begin{array}{c}\text { Desired carbon-dioxide }\left(\mathrm{CO}_{2}\right) \\
\text { level }\end{array}$ & $\%$ & $5-8$ \\
\hline $\begin{array}{l}\text { Required permeability of film } \\
\text { OTR } \\
\text { CTR }\end{array}$ & $\begin{array}{l}\mathrm{cc} / \mathrm{m}^{2} \text {-day-atm } \\
\mathrm{cc} / \mathrm{m}^{2} \text {-day-atm }\end{array}$ & $\begin{array}{c}92505.1 \\
257160.2 \\
\end{array}$ \\
\hline $\mathrm{O}_{2}$ permeance & $\mathrm{cc} / \mathrm{m}^{2}-\mathrm{h}-\mathrm{kPa}$ & 31798.0 \\
\hline $\mathrm{CO}_{2}$ permeance & $\mathrm{cc} / \mathrm{m}^{2}-\mathrm{h}-\mathrm{kPa}$ & 42570.1 \\
\hline Number of holes per side & number & 10 \\
\hline Hole diameter & $\mathrm{mm}$ & 0.5 \\
\hline Storage temperature & ${ }^{\circ} \mathrm{C}$ & 14 \\
\hline RH & $\%$ & $90-95$ \\
\hline
\end{tabular}

\subsection{Shelf life}

The control mangoes fruits had a shelf-life of 12 days. However, MA packed (LDPE, $75 \mu \mathrm{m}$ ) with ethylene absorbents samples was found to have a shelf-life of 42 days at refrigerated conditions plus 5 days at ambient after opening of MA packages (Table 3; Fig 3).

Table 3: Quality parameters for shelf life

\begin{tabular}{|c|c|c|}
\hline $\begin{array}{c}\text { Parameters (after } \\
\begin{array}{c}\text { 6 weeks of } \\
\text { storage) }\end{array}\end{array}$ & with out MAP & $\begin{array}{c}\text { MAP with ethylene } \\
\text { absorbents (PP+SA) }\end{array}$ \\
\cline { 2 - 3 } & 0.27 & 2.11 \\
\hline Firmness, Kg & 1 & 15.2 \\
\hline TSS, ${ }^{\circ B x}$ & 22.4 & 3.7 \\
\hline PLW, \% & - & $\begin{array}{l}\mathrm{O}_{2}-6.2 \% \\
\mathrm{CO}_{2}-7.8 \%\end{array}$ \\
\hline $\begin{array}{c}\text { Gas composition } \\
\text { inside MA packs }\end{array}$ & 3 & 6 \\
\hline Shelf life, weeks & (Plus 5 days) \\
\hline
\end{tabular}




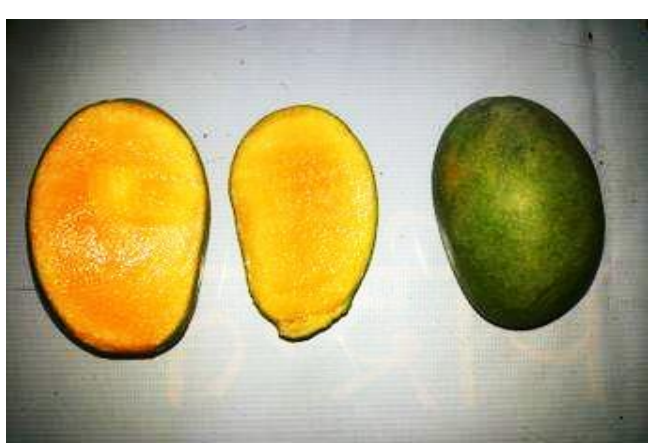

Fig.3 MAP (PP+SA) packed fully ripe mango after 6 weeks in refrigerated MA storage and addition 5 days storage at room temperature.

\section{Conclusions}

1) The respiration rate was found to be temperature dependent and the rates were increased with temperature for mango. The reparation rate in terms of $\mathrm{CO}_{2}\left(\mathrm{ml}-\mathrm{CO}_{2} / \mathrm{kg} \mathrm{hr}\right)$ evolution was 16.12 at $10^{\circ} \mathrm{C}$ temperature.

2) Based on design calculation, polymeric film LDPE (75 $\mu \mathrm{m}$ ) thickness for bulk packaging of Mango with perforations were found suitable for MAP studies for shelf life enhancement. The number and diameter of perforations were optimized to match the required $\mathrm{O}_{2}$ and $\mathrm{CO}_{2}$ permeability.

3) The active packaging techniques had improved the shelf life of mango. Using ethylene absorbent, the shelf-life of MA packed mango was enhanced up-to 7 weeks.

\section{References}

F.A.Paine, (1991), The packaging users handbook. Van Nostrand Reinhold, New York, USA: AVI.

G,Robertson (2006), Food packaging principles and practices, Boca Raton, Fla: Taylor \& Francis.

K.L.Yam, P.T.Takhistov, J.Miltz, 92005) Intelligent packaging: concepts and applications, J Food Sci, 70,1-10.

J.Miltz, N.Passy, C.H.Mannheim, (1995), Trends and applications of active packaging systems. In: Jagerstad M, Ohlsson M, editors. AckermanP. London, England: Food and packaging materials-Chemical interaction. The Royal Society of Chemistry,pp.201-210.
M.L.Rooney, (1995), Overview of active food packaging, In: Rooney ML, editor, Active food packaging, Glasgow: Blackie Academic \& Professional,pp.1-37.

R.Ahvenainen,(2003), Active and intelligent packaging: an introduction, In: Ahvenainen R, editor, Novel food packaging techniques. Cambridge UK: Wood head Publishing Ltd,pp.521.

M.L.Sivertsvik, (2007), Lessons from other commodities: Fish and meat, In: Wilson $\mathrm{CL}$, editor, Intelligent and active packaging for fruits and vegetables, Boca Raton, London, CRC press,pp.151-161.

G. Robertson, (2006), Food packaging principles and practices, Boca Raton, Fla: Taylor \& Francis.

A.L.Brody, B.Bugusu, J.H.Han, M.T.Hugh, (2008), Innovative food packaging solutions, J Food Sci ,73,8,107-116.

S.A.Hogan, J.P. Kerry, (2008), Smart packaging of meat and poultry products, In: Kerry J, Butler P, editors, Smart packaging technologies for fast moving consumer goods, West Sussex, England, John Wiley \& Sons Ltd,pp.3359.

A.Lopez-Rubio, E.Almenar, P.Hernandez-Munoz, J.M.Lagaron, R.Catala, R.Gavara, (2004), Overview of active polymer based packaging technologies for food applications. Food Rev Int, 20,4, 357-387.

T.P.Labuza, (1996), An introduction to active packaging for foods. Food Technol, 50,68-71.

P. Appendini, J.H.Hotchkiss, (2002), Review of antimicrobial food packaging. Innov Food Sci Emerg,3,113-126.

L.Vermeiren, F.Devlieghere, M.VanBeest, N.deKruijf, J.Debevere,(1999), Developments in the active packaging of foods, Trends Food Sci Tech,10,77-86.

F.B.Abeles, P.W.Morgan, M.E.Saltveit,(1992), Ethylene in plant biology. San Diego, California: Academic press Inc.

D.Zagory,(1995), Ethylene-removing packaging, In: Rooney M.L, editor. Active food packaging. London, UK: Blackie Academic and Professional,pp.38-54.

B.P.F. Day,(2003), Active packaging, In: Coles R, McDowell D, Kirwan M, editors, Food packaging technologies, Boca Raton, FL, USA: CRC press, pp.282-302.

M.L.Rooney,(2005), Introduction to active food packaging technologies, In: Han JH, editor, Innovations in Food Packaging. London, UK: Elsevier Ltd, pp.63-69.

D.R. Rai, S.Paul, (2007) Transient state in-pack respiration rates of mushroom under modified atmosphere packaging based on enzyme kinetics, Biosystems Engineering, 98, 319326.

R.Singh, S.K.Giri,K.V.R.Rao, (2014), Respiration rate model for mature green capsicum (Capsicum annum L.) under closed aerobic atmospheric conditions, Croat. J. Food Sci. Technol,6,2, 110-115. 